\title{
Waiting for Breakthrough in Conventional Submarine's Prime Movers
}

\section{Tomasz Lus}

Submarines, as a very expensive and sophisticated type of weaponry, are being intensively exploited by the armed forces of many countries. This means that submarines are sent ever longer patrols, sometimes to distant regions. To meet such requirements, submarine sub-systems and components must have high reliability and operational readiness indicators. Among the many machines and devices found on submarines, the ones that generate, store, and consume energy (mainly electricity) deserve special attention. The largest energy consumers on the submarine are the components of its propulsion system. One of the most complicated and loaded devices on board submarine is a power generator with a diesel engine driving it, on whose continuous and reliable work the safe performance of tasks depends. According to statistical research, despite its importance for the process of performing tasks by submarines, diesel engines are still the least reliable devices on submarines. Despite the constant technological development of piston engines, their work in very difficult conditions under heavy load and at high counterpressure at the exhaust outlet promotes their malfunction and damage. From this point of view, the development of charge air

\section{KEY WORDS}

$\sim$ Submarine

$\sim$ Prime mover

$\sim$ Diesel engine

$\sim$ Battery \& air independent propulsion

Mechanical and Electrical Engineering Faculty, Polish Naval Academy, Poland e-mail: t.lus@amw.gdynia.pl

doi: 10.7225/toms.v08.n01.004

This work is licensed under (cc) BY systems for submarine diesel engines based on the construction experience of MTU Company is described in the paper. The classification of submarines, their propulsion systems, and the working conditions of engines on submarines are presented in the paper. Air-Independent Propulsion (AIP) systems with their applications on chosen submarines are also described. The most significant change in submarine propulsion system observed in 2018, transition from lead-acid to lithium-ion batteries, is also presented.

\section{INTRODUCTION}

Submarines are an important element of the naval forces of many countries. They can be classified, among other things, by their displacement, type of weapons carried, and type of propulsion system. Only the richest and largest countries (the USA, Russia, Great Britain, France, China, and India) operate submarines with nuclear propulsion and nuclear weapons. This is due to the very large construction / purchase and operation costs of such ships. Other countries such as Brazil and North Korea also aspire to this group. About 40 smaller and less wealthy countries operate smaller submarines with conventional weapons and propulsion systems.

SSBN submarines are carriers of ballistic missiles, SSGN submarines are equipped with missiles other than ballistic, and SSN submarines are carriers of conventional and nuclear torpedoes and mines. These types of submarines equipped with nuclear propulsion may theoretically, because of the source of energy which is the nuclear reactor, stay under water for a very long time, limited only by the time of nuclear fuel burning, even up to several years. Practically, the length of patrols carried out by SSBN, SSGN, and SSN craft is limited by the physical and psychological strength of the crews and other limitations not related to the propulsion system. 
Things are quite different in the case of non-nuclear SSK submarines with conventional propulsion. The time of staying under water of these craft is determined mainly by limitations related to the propulsion system. In particular, the need to recharge batteries requires the craft to emerge or, if the snorkel system is used, the snorkel mast is raised above the water surface. Piston combustion engines driving the generators require large amounts of air to be delivered and exhaust gases removed. Battery charging time depending on the degree of their discharging can range from several dozen minutes to several hours. The period in which a submarine with the conventional drive charges batteries is very unfavorable from the point of view of secret operation - one of the most important features of the submarine. In order to minimize the probability of submarine's detection by the opponent, the aim is to increase the range of submarine's navigation in immersion by expanding the battery systems, increasing their capacity, eventually installing mechanical and electrical energy generating systems for submarines capable of operating without access to atmospheric air - AIP systems.

\section{SUBMARINE DIESEL ENGINES}

Due to the high concentration of power required and the resistance to intake air pressure depression, increased backpressure at the exhaust outlet, most modern submarines use high-speed, four-stroke, single-acting, exhaust gas turbocharged diesel engines to charge the battery when on surface or during snorkel. Historically, the four-stroke naturally aspirated mediumspeed diesel engines, and then two-stroke diesel engines were used in submarines. The four-stroke naturally aspirated diesel engines which suck the air directly from the submarine engine room compartment through the filters had relatively low power. So, because of the power needed (to charge the submarine's battery and drive the screw propeller at the same time), more powerful two-stroke diesel engines, with Roots displacement blowers driven from the crankshaft of the engine, began to be used. In the meantime, on most of the conventional submarines direct mechanical drive of the propeller has been abandoned. The era of high-speed, four-stroke diesel engines with exhaust gas turbocharging has come.

The presented development of four-stroke submarine diesel engines focused on their charge air system based on MTU's operational experience [13].

\subsection{Naturally Aspirated Diesel Engines}

In naturally aspirated diesel engines, the pistons create a negative pressure in the air intake system in order to suck air into the combustion chamber (Figure1). Due to high vacuum on the air intake duct and high back pressure at the outlet, the valve opening times must be limited to a short time window (small angular range). The engine power is therefore relatively low, and the specific fuel consumption is high. MTU used this concept in the $12 \mathrm{~V} 493 \mathrm{AZ}$ type engines intended for submarines, which have a power of $455 \mathrm{~kW}$ at a rotational speed of 1,500 rpm.

\subsection{Diesel Engines with Mechanically Driven Supercharger}

In engines with mechanically driven supercharger, additional air mass is supplied to the combustion chambers of the engine (Figure 2). This results in a greater mass of available air for the combustion process, i.e. more fuel can be converted into thermal energy and then into mechanical and electrical energy. Compared to naturally aspirated engines, the efficiency of such
1

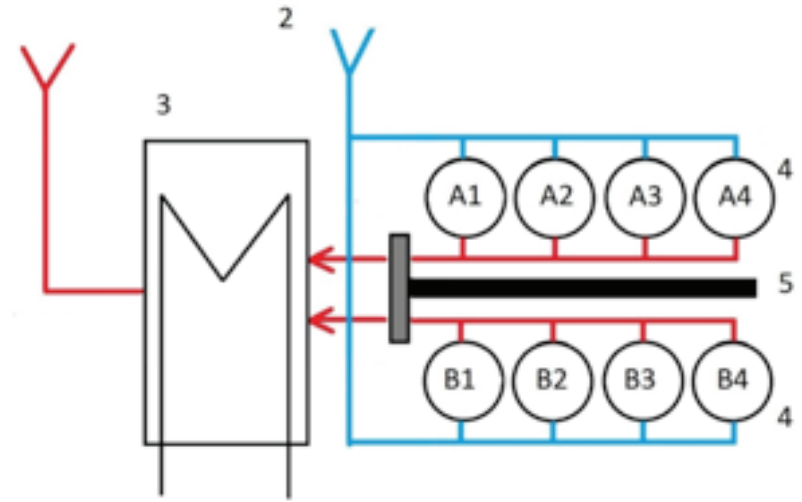

Figure 1.

Air flow diagram in naturally aspirated engine A1-A4, B1-B4 - cylinders, 1 - exhaust gas outlet, 2 - intake air inlet, 3 - exhaust gas cooler/silencer, 4 - combustion chambers/cylinders,

5 - crankshaft and flywheel.

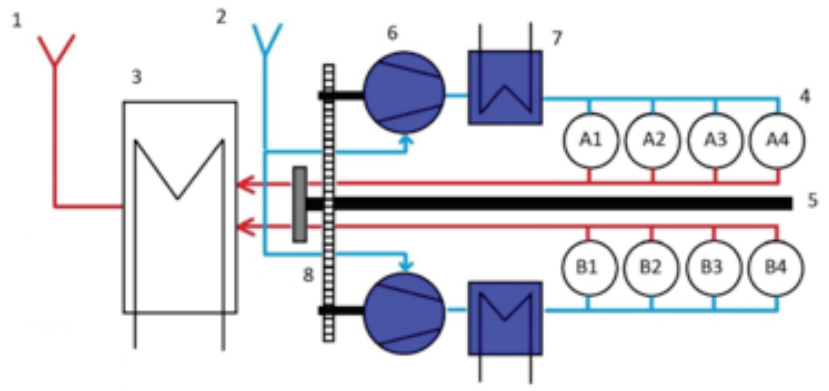

Figure 2.

Air flow diagram in engine with mechanically driven supercharger

A1-A4, B1-B4 - cylinders, 1 - exhaust gas outlet, 2 - intake air inlet, 3 - exhaust gas cooler/silencer, 4 - combustion chambers/cylinders, 5 - crankshaft and flywheel, 6 intake air compressor, 7 - intake air cooler, 8 - engine gear train 
an engine on nominal loads is greater, but mechanical losses remain the same. Assuming that the compressor power demand is linearly proportional to the engine speed, engine work with a partial load at constant crankshaft speed (required on the submarine), results in a significant deterioration of the specific fuel consumption. Engines with a mechanically driven air compressor (Figure 2) are relatively insensitive to changes in backpressure at the outlet as the compressor is mechanically connected to the crankshaft. For submarines, MTU has implemented such a solution in 16V 652 MB type engines with the power of 1,200 kW at a rotational speed of $1,400 \mathrm{rpm}$.

\subsection{Diesel Engines with Exhaust Gas Turbocharging}

As in the case of the mechanically driven supercharger, a compressor supplies additional mass of air to the engine. However, the exhaust gas driven compressor (turbocharger) is mechanically separated from the engine (Figure 3 ). The power to drive the compressor is therefore not taken from the crankshaft, but is obtained by using the energy contained in the exhaust gases, through a turbine mounted on the same shaft as the compressor. The higher combustion air mass delivered in this way can be used to burn more fuel. By using the energy contained in the exhaust gas to drive the turbocharger, the efficiency of the engine can be increased at the rated power as well as at partial loads. Turbocharged engines were introduced on submarines in the 1980s. The reason for their relatively late implementation on submarines compared to other applications (surface ships since the 1950s) was that engines with standard turbochargers could not work with the required reliability index without special adaptation. This adaptation was required to meet the operating conditions of submarines. Appropriate technical solutions have been developed to ensure the safe operation of engines with the occurrence of intake air pressure depression on the inlet and high backpressure at the engine exhaust. In 1976, MTU started to develop, produce, and test turbochargers specially designed for work on submarines. In comparison to standard turbochargers, these turbochargers have larger compressor rotors and smaller turbine rotors, which increase their field of work. A large compressor rotor is required to ensure a sufficient volume of air flow under reduced pressure at the engine intake. On the outlet gas side, a small turbine rotor is needed due to the high pressure of the water column above the exhaust gas outlet from the engine. The difference in dimensions between the turbocharger for a submarine and the standard turbocharger results from the differences in pressure values at the inlet and outlet of the engine. A wider range of work area is required due to pressure fluctuations caused by sea waves during work on the snorkel and in the surface position. Due to large differences in pressure and continuous engine load changes due to changes in wave height, special attention must be paid to the seals as well as to the turbocharger impeller bearings. The turbocharged engine of MTU family 396, type 16 V396 SE84 develops power of 1,200 $\mathrm{kW}$ at a rotational speed of $1,800 \mathrm{rpm}$.

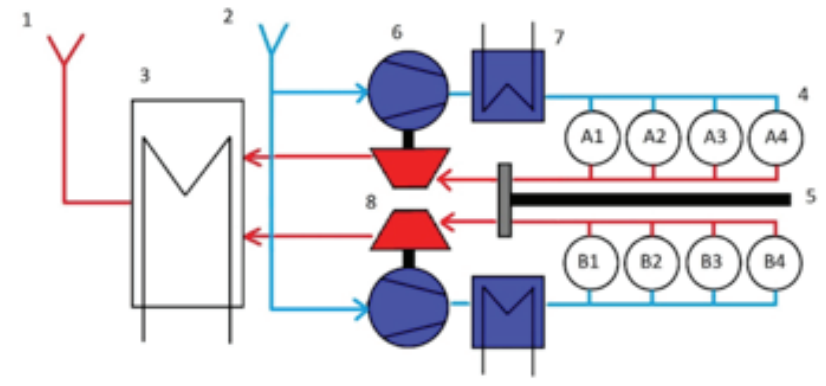

Figure 3.

Air flow diagram with exhaust gas turbocharger A1-A4, B1-B4 - cylinders, 1 - exhaust gas outlet, 2 - intake air inlet, 3 - exhaust gas cooler/silencer, 4 - combustion chambers/cylinders, 5 - crankshaft and flywheel, 6 - intake air compressor, 7 - intake air cooler, 8 - exhaust gas turbine.

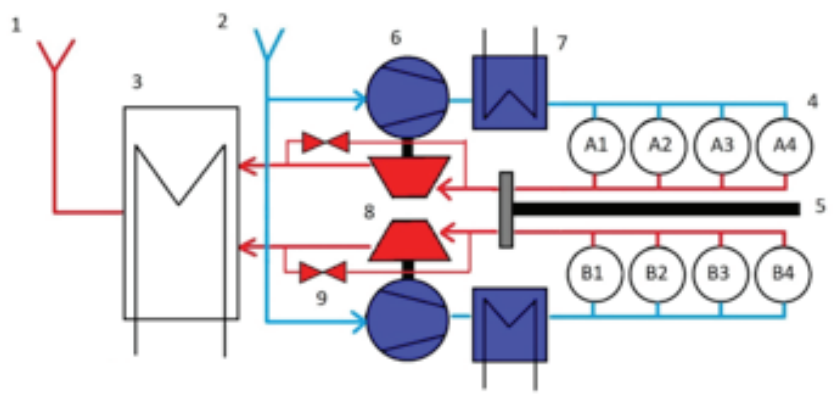

Figure 4.

Air flow diagram with exhaust gas turbocharger and waste gate

A1-A4, B1-B4 - cylinders, 1 - exhaust gas outlet, 2 - intake air inlet, 3 - exhaust gas cooler/silencer, 4 - combustion chambers/cylinders, 5 - crankshaft and flywheel, 6 - intake air compressor, 7 - intake air cooler, 8 - exhaust gas turbine, 9 - exhaust gas bypass/waste gate.

\subsection{Diesel Engines with Exhaust Gas Turbocharging and Waste Gate}

This charging system alternative (Figure 4) is a further development of the system with turbocharger. It contains valves that open and close the bypass of the turbine depending on the charge air mass, back pressure at the outlet, temperature of the intake air and exhaust gases as well as the rotational speed of the turbocharger. This allows the turbocharger to maintain constant speed regardless of the fluctuations in the intake air pressure depression and exhaust gas backpressure, ensuring 
constant volumetric flow to the combustion chambers. Thus, the geometry of the turbine can be even better suited to the working conditions with backpressure. The turbocharger performance map can be further optimized in this way depending on the fuel consumption at the rated load as well as at partial loads while maintaining the emission limits. Another advantage of the constant volumetric air flow is the constant value of the maximum combustion pressure, which reduces the stresses of the combustion chamber components that may occur at a variable mass of air flow. This results in longer periods between technical services and lower noise emissions. This solution also provides other benefits regarding operating engine safety, particularly in situations without back pressure at the exhaust (engine operation when submarines surface). This solution of the turbocharger with the waste valve is used in MTU engines Series 4,000 optimized for operation in submarines. Engines of this family, type $12 \mathrm{~V} 4000 \mathrm{U} 83$ develop the power of 1,300 kW at a rotational speed of $1,800 \mathrm{rpm}$.

\section{SUBMARINE AIP SYSTEMS}

Different than diesel engines, systems that can generate mechanical (and then/or electrical) energy on submarines without access to atmospheric air have been known since the very beginning of submarines, when stored compressed air was used to move the propeller of the craft. The application of the AIP system at the end of World War II on the German submarine is far better known, with a turbine driven by steam-gas obtained from the reaction of hydrogen peroxide with water, and developed by Walther. After the Second World War, several countries with greater or lesser success conducted research and built submarines with analogous and similar systems of turbines and diesel engines working in semi-closed cycle. The breakthrough in the construction of submarine underwater propulsion systems took place in the 1950s, when the US built the first submarine with nuclear propulsion - USS Nautilus. This drive has made submarine really a submarine, and not what it had been up to that point, i.e. a submersible ship with the need to resurface to charge battery for a definite time. Nuclear drive has caused the largest countries to limit or discontinue development and testing other than nuclear AIP systems for submarines. This idea was sustained in smaller countries such as Sweden, the Netherlands, or Germany. The last decades of the twentieth century were devoted to intensive research on AIP systems such as: a diesel engine working in a semi-closed cycle - Close Cycle Diesel (CCD) engine, external combustion piston engine operating in semi-closed cycle - Stirling engine, turbine working in a closed Rankine cycle driven by steam generated by heat from alcohol combustion in the semi-closed system - DCNS MESMA system, and low-temperature fuel cells - PEM Fuel Cells. Approximate indicators of AIP modules are presented in Table 1.

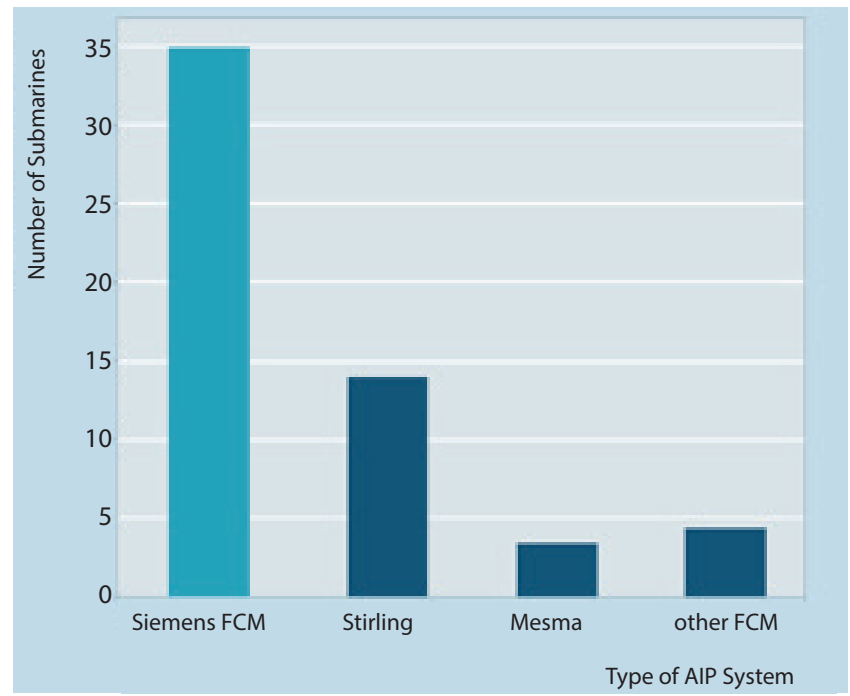

Figure 5.

Comparison of installed /contracted AIP systems (Siemens, 2013).

Table 1.

Approximate indicators of AIP modules.

\begin{tabular}{lllll}
$\begin{array}{l}\text { AlP type/ } \\
\text { Ship type }\end{array}$ & $\begin{array}{l}\text { Approx. } \\
\text { AIP } \\
\text { module } \\
\text { Mass } \\
{[\mathrm{kg}]}\end{array}$ & $\begin{array}{l}\text { AIP } \\
\text { module } \\
\text { Power }\end{array}$ & $\begin{array}{l}\text { Power to } \\
\text { Mass } \\
\text { Coefficient }\end{array}$ & $\begin{array}{l}\text { Approx. } \\
\text { AIP } \\
\text { Efficiency }\end{array}$ \\
$\begin{array}{l}\text { PMEFC/ } \\
\text { PNW/kg] }\end{array}$ & {$[\%]$} \\
$\begin{array}{l}\text { Stirling/ } \\
\text { A19 }\end{array}$ & 600 & 120 & 0.13 & 60 \\
$\begin{array}{l}\text { MESMA/ } \\
\text { Agosta } \\
\text { 90B }\end{array}$ & 3000 & 200 & 0.06 & 35 \\
\hline
\end{tabular}

Recently, the most popular types of AIP systems (Fig. 5) installed in combat submarines are: Proton Exchange Membrane Fuel Cells (PEMFC), external combustion piston engines (Stirling engine), and Rankine cycle power turbine (MESMA). CCD AIP systems, although effectively tested (including real submarines) in some countries, so far have not found a practical application on submarines. This is due to their low efficiency and higher acoustic emission than the three other systems mentioned above. 


\subsection{PEM Fuel Cell AIP System}

The first PEMFC AIP systems were installed in four German 212 class submarines in the period from 2005 to 2007. The propulsion plant of the 212 submarine combines a conventional system consisting of a diesel engine and a lead acid battery, with the PEMFC AIP system used for cruising at slow speed. The AIP system consists of seven PEMFCs, providing between 30 and 50 kW each (Fig. 6). The oxidant is liquid oxygen (LOX tank is installed inside the pressure hull), and the fuel is hydrogen, stored in metal hydride cylinders outside the pressure hull (Fig. 6). Another type of German submarines, the type 214, (sold to the South Korean Navy) has a similar AIP system with two modernized Siemens PEMFC modules that produce max. $120 \mathrm{~kW}$ each. Thanks to this system, the submarine could spend under water approximately 2 weeks without snorkeling.

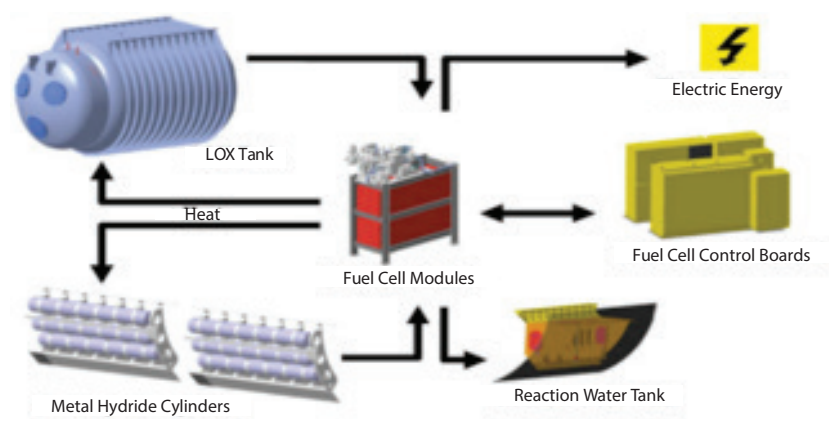

Figure 6.

Overview of Fuel Cell System components (Krummrich, 2010).

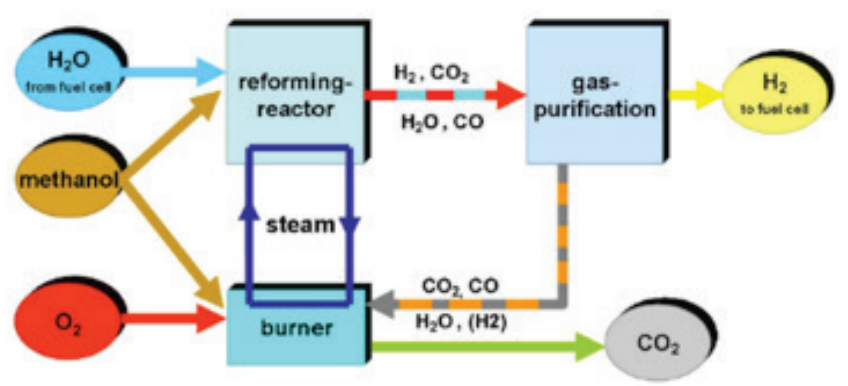

Figure 7.

Overview of Methanol Reformer System (Krummrich, 2010).
In a new submarine AIP system's technology development, the most important are higher amounts of stored fuel (hydrogen) and oxidant. The amount of hydrogen stored onboard is limited by the size of the submarine, especially as the system based on metal hydride storage is relatively heavy (Krummrich, 2010). This prompted the German submarine manufacturer HDW to develop reformer system (Fig. 7) for onboard hydrogen production from methanol. Two other feedstocks (Diesel fuel and ethanol) were also considered, but methanol was chosen because of the highest $\mathrm{H} / \mathrm{C}$ ratio, highest efficiency of the reforming process, high hydrogen purity, very easy reformation at low temperature (app. $250 \circ$ o ), and worldwide availability.

\subsection{Stirling Engine AIP System}

Stirling engine AIP systems (Fig. 8, 9), first installed in the Swedish Navy submarines Gotland and Nacken, are energy conversion devices that operate over a semi-closed, regenerative thermodynamic cycle. The power pistons operate in a closed helium (or hydrogen) working gas system, and heat is continuously transferred to the cycle via a heat exchanger. The oxidant of the AIP system is liquid oxygen, which is stored inside the pressure hull, and the fuel is Diesel oil. As the combustion chamber is external and separated from the working gas, it is possible to select the pressure of the combustion chamber. A relatively high combustion pressure allows the exhaust products to be discharged overboard at depth through a special mixing unit, where the carbon dioxide is dissolved in the seawater cooling system. Besides AIP system, Gotland submarine is equipped with two 970 kW Diesel engines. Two Kockums Stirling AIP units, which provide up to $75 \mathrm{~kW}$ each, provide over 14 days submerged endurance without snorkeling.
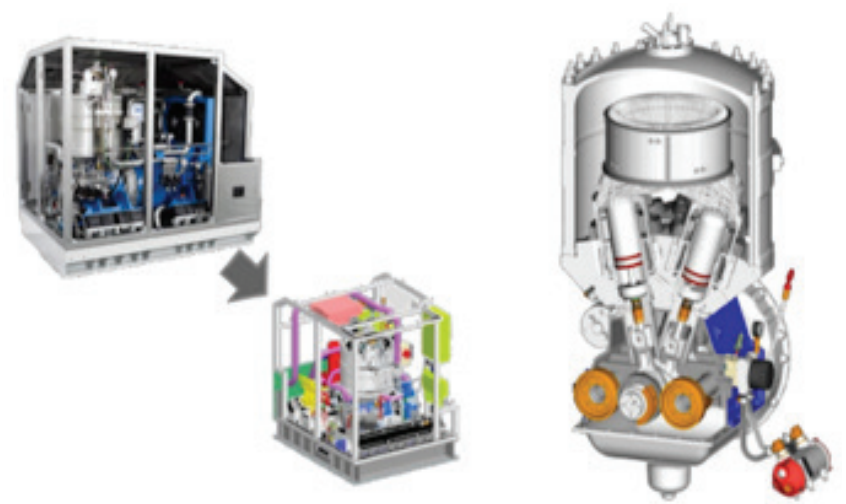

Figure 8.

Stirling Mark 3 to Mark 5 transition (from 200 to 250 meters under water surface) (Saab, 2015). 


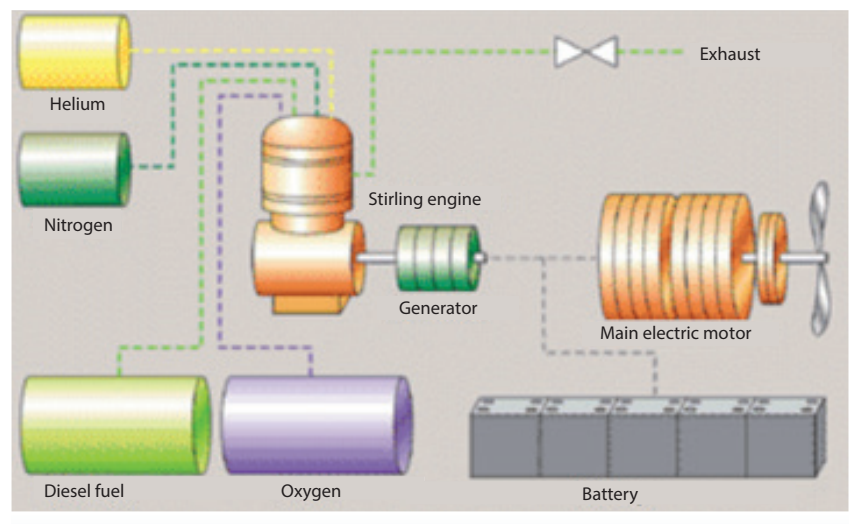

Figure 9.

Schematic of Stirling engine operation (Kukums Shipyard Website).

\subsection{MESMA AIP System}

The French DCNS Module Energie Sous-Marin Autonome (MESMA) system (Fig. 10) is an AIP system whose operation is based on a closed steam Rankine cycle. Liquid oxygen (stored in LOX tanks at $-185 \circ \mathrm{O}$ ) is pumped into a vaporizer, where it becomes gaseous. It is then led into the combustion chamber, where it mixes with ethanol, and burned produces hot gasses of temperature of $700 \mathrm{o} \mathrm{C}$, at a pressure of $60 \mathrm{bar}$, to heat the secondary cycle. The high pressure of the exhaust gases allows for operation of the system at any diving depth without the need for additional equipment. The secondary circuit is a steamdriven turbine which drives a high-speed generator with output of about $200 \mathrm{~kW}$. DCNS developed MESMA AIP system as a submarine hull module (Fig.11) which could be used for new ships and for retrofit.

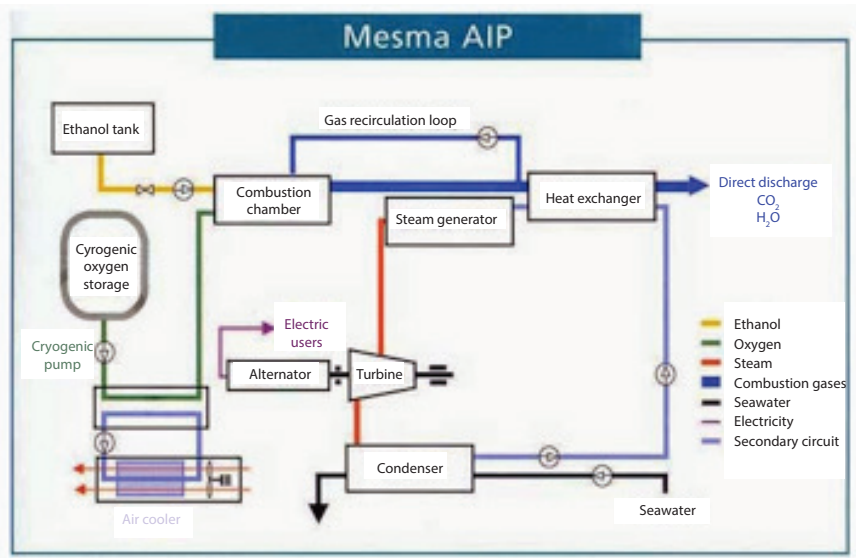

Figure 10.

MESMA AIP system diagram [DCNS].

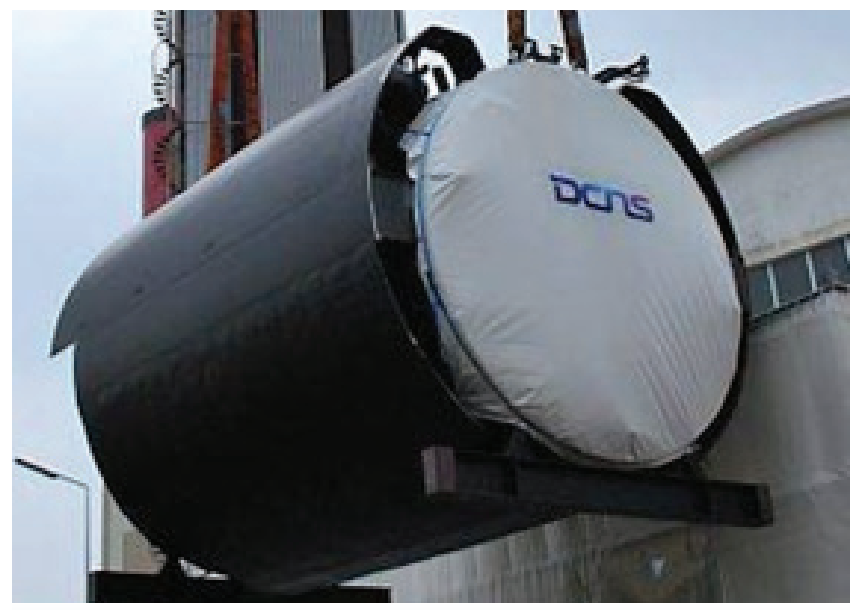

Figure 11.

MESMA AIP system module [DCNS].

\section{SUBMARINE BATTERIES}

A Polish engineer, Stefan Drzewiecki, in the tsarist Russia (Kuźmicki, 2006) in 1883 was the first to install onboard a submarine an electric motor and electric batteries for its power supply. This system has become a canon on submarines as invented by John Holland Diesel-electric propulsion system. Batteries are standard features in all types of submarines (Koon, Kong \& Wee, 2011) to provide standby and propulsion power. Prior to the advent of AIP and nuclear technology, a submarine's submerged endurance depended entirely on its battery life. Thus, the time required to charge its batteries remains as one of the submarine's key performance indicators - this determines how long a submarine has to snorkel and risk detection by adversaries.

\subsection{Lead-Acid Batteries}

Lead-acid batteries are commonly used (Kuźmicki, 2006) today and are one of the main elements of the submarine propulsion system despite a rather embarrassing exploitation (Fig. 12). Electric drive application involves the necessity of a periodic surface of the craft or positioning it on the periscope/ snorkel depth and charging the batteries. The use of electric drive also significantly reduces the underwater speed of the ship, and the range decreases along with increasing speed. Even now at the speed "full ahead", the consumption of battery current is so high that it limits the craft's movement only to a time not much longer than 1 hour and in some ship types much below this value. However, modern submarine's lead-acid double-decker batteries are powerful, effective, reliable, and long-lasting. Lead acid batteries have high capacity during discharge, high current capability during discharge, low gassing, low $\mathrm{H} 2$ evolution during operation, and good shock resistance (EverExceed, 2019). Lead- 
acid batteries also have some drawbacks, so they are provided with built-in cooling systems, built-in acid circulation systems, and battery monitoring systems. All the time from Drzewiecki's invention the research works have been underway to prepare other types of batteries for submarines than the lead-acid type. Greater efficiency than from lead-acid batteries is provided by high-temperature sodium-sulfur batteries, sodium-nickel-sulfur batteries, and lithium-ion batteries.

\subsection{Lithium-Ion Batteries}

While lead-acid batteries have been the standard used in submarines, their dominance is increasingly challenged by a new generation of batteries that offer better power and energy density. Lithium-ion (Li-ion) batteries are currently one of the most popular types of battery for portable electronics (Koon, Kong \& Wee, 2011). They have a superior energy-to-weight ratio and a slow loss of charge when not in use. Lithium is one of the lightest metals and has great electrochemical potential. In addition to the wide-ranging applications of Li-ion batteries in the consumer electronics domain, there is also a growing demand for it in the defense, automotive, and aerospace industries. This is due to the high energy density and technological maturity of Li-ion batteries. Figure 13 shows a simplified diagram of the charging and discharging sequence of a Li-ion battery. One of the key advantages of Li-ion batteries is their ability to be molded into different shapes and sizes to fill any space available in the devices they power efficiently. It has a low self-discharge rate of approximately five to ten percent, which is significantly lower in comparison with other battery types in the market. No memory and scheduled cycling is needed to prolong the battery life. Due to these desirable traits, Li-ion battery systems were tested for application in underwater vehicles and have demonstrated high potential in replacing lead-acid battery systems in Diesel-electric submarines.

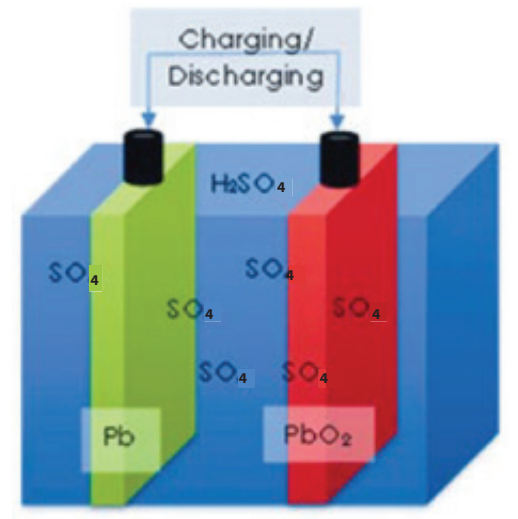

Figure 12.

Operation of lead-acid battery (Koon, Kong \& Wee, 2011).

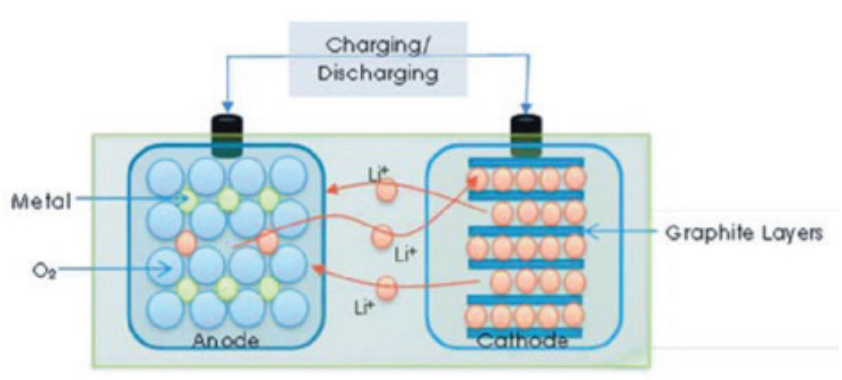

Figure 13.

Charging and discharging sequence of a Li-ion battery (Koon, Kong \& Wee, 2011).

On 04 October, 2018, Japan's first submarine powered by lithium-ion batteries was launched (Fig. 14, 15). The 84-meterlong Oryu was lowered into the water (Rogoway, 2017) at the Kobe shipyard of Mitsubishi Heavy Industries. The submarine can reach speeds of approx. 20 knots and displaces 2,950 tons. It should be delivered to the Japan Maritime Self-Defense Force in March 2020. The Oryu is the eleventh submarine based on the Soryu's design. The Soryu-class vessels, which started being built in 2005, are among the largest Diesel-electric submarines in the world. The Oryu is a significantly updated version of the Soryu, the biggest change being the replacement of lead-acid batteries with lithium-ion ones. Mitsubishi tapped GS Yuasa to supply the high-performance batteries, which store about double the power of lead-acid batteries. Submarine batteries are recharged by the energy generated by Oryu's diesel engines. The craft switches to batteries during operations and actual combat in order to silence the engines and become harder to detect. The lithium-ion batteries radically extend the sub's range and time it can spend underwater.

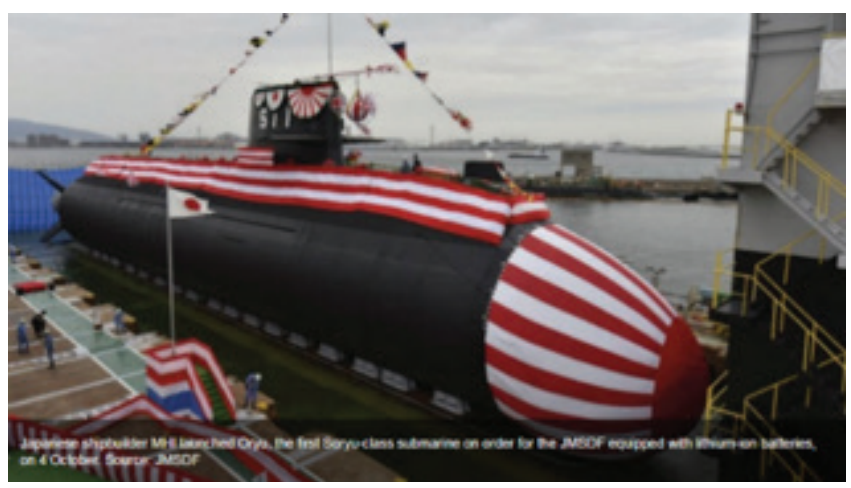

Figure 14

The Oryu, Japan's first submarine to run on lithium-ion batteries, launched in Kobe

(Photo by Kenji Asada)(Rogoway, 2017). 


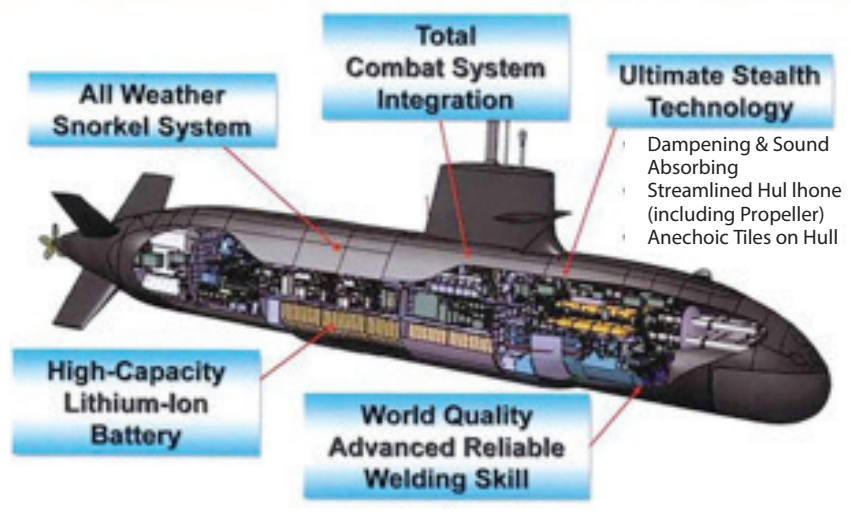

Figure 15.

The Oryu submarine visualization with lithium-ion battery (Rogoway, 2017).

The similar announcement released by South Korea says that it has developed lithium-ion batteries that can double the operational hours of submarines compared to those with leadacid batteries. The lithium-ion batteries were created for the country's next-generation attack submarines, expected to be launched in the mid-2020s, according to the Defense Acquisition Program Administration (DAPA). Samsung SDI manufactured the battery module to be mounted on the second batch of three KSS-III submarines. Hanwha Land Systems is responsible for integrating the modules and other parts on the submarine, which is built by Daewoo Shipbuilding \& Marine Engineering. According to the DAPA, the KSS-III class is 83.5 meters long and has a beam of 9.6 meters. It has a displacement of 3,358 tons when surfaced, and 3,705 tons when submerged.

In the same year 2018 (Thyssen Krupp MS, 2018), Thyssen Krupp Marine Systems also announced to have developed a new type of lithium-ion battery system for submarines together with Saft, a manufacturer of advanced battery systems for the industry. In an adapted form, the system could also be used for other maritime applications in future. Thyssen Krupp Marine Systems have presented the prototype at the EURONAVAL for the first time to the public. Saft specializes in advanced technology battery solutions for the industry, from the design and development to the production, customization, and service provision. Saft is a wholly-owned subsidiary of Total, the leading international oil-and-gas company.

Also in 2018, Naval Group announced (Naval Group, 2018) to have developed a high performance and highly secure Li-ion battery system (also together with Saft) to provide its conventional submarines with outstanding operational capabilities as well as an immersion period and reloading time largely optimized. The navies that will operate this new technology will boast a major technological superiority on the theatres of operations. This success is the result of a close cooperation between Naval Group, Saft, CEA Tech, and EDF R\&D. The Li-ion battery system, LIBRT, improved security and performances on-board submarines developed by Naval Group. LIBRT increases significantly the submarines' submerged endurance and improves its stealth while guaranteeing better security conditions. This cutting-edge technology offers twice more available energy while reducing significantly the reloading time.

\section{CONCLUSIONS}

The next few years will show if the Li-ion batteries (really the cutting-edge technology) makes a breakthrough in the submarine propulsion systems similar to nuclear reactors. Many specialists think so although there are always those who are afraid. Especially after the fire of a Tesla car.

So far, high-speed, four-stroke diesel engines with exhaust gas turbocharging have been used for submarine generator drive. The power and the number of engines depend on the size of the craft and battery capacity. Possibly, with the implementation of lithium-ion batteries even higher power generators will be needed.

Regardless of the success or failure to implement lithium-ion batteries for submarines, AIP systems will still be a very desirable equipment, increasing the possibilities of their operation.

\section{REFERENCES}

Psallidas, K., Whitcomb, C.A., Hootman, J.C., 2010. Design of Conventional Submarines with Advanced Air Independent Propulsion Systems and Determination of Corresponding Theater-Level Impacts. MIT, Cambridge.

Krummrich, S., 2010. Fuel Cell Methanol Reformer System for Submarines, 18th World Hydrogen Energy Conference 2010 - WHEC 2010, Parallel Sessions Book 3: Hydrogen Production Technologies - Part 2, Proceedings of the WHEC, Essen, May $16-21$.

Submarine Matters. Available at: https://saab.com/naval/\#Submarines-andSurface-Ships.

SAAB, 2015. Super stealthy submarines. Available at: https://saab.com/region/saabaustralia/about-saab-australia/latest-news/stories/stories---australia/2015/superstealthy-saab-submarines/.

SINAVY PEM Fuel Cell for Submarines, 2013. Siemens AG.

Kukums shipyard, 2019. Official web site.

Kuźmicki, S., 2006. Evolution of the submarines from the 1950s / Ewolucja napędu okrętów podwodnych od połowy XX wieku. ZESZYTY NAUKOWE AKADEMII MARYNARKI WOJENNEJ ROK XLVII NR 3 (166), Gdynia.

Submarine batteries, 2019. EverExceed Corporation.

Koon, O.L., Kong, L.C., Wee, T.C., 2011. Introduction to Submarine Design, DSTA HORIZONS. 
Rogoway, T., 2017. Diesel electric submarines may be on the verge of returning to their simpler roots with the help of lithium-ion batteries, War Zone, issued February $17^{\text {th }}$.

EuroNaval, 2018. New Lithium-Ion Batteries for Submarines: Prototypes to be Presented at EuroNaval, Defense Aerospace, Thyssen Krupp Marine Systems, issued October $19^{\text {th }}$.
Naval Group Presents LIBRT, 2018. Its New Generation of Lithium-lon Batteries System for Submarines, Defense Aerospace, Naval Group; issued October $22^{\text {nd }}$.

von Drathen, A., Charge Air Systems for Submarine Engine. Engine technology, MTU Friedrichshafen GmbH - a Rolls-Royce Power Systems Company. Available at: https://www.mtu-online.com. 